\title{
MANAGEMENT OF MADHUMEHAJ VRANA (DIABETIC FOOT ULCER) THROUGH JALAUKAVCHARANA: CASE REPORT
}

Dr. Balyogeshwar Sharma

\author{
Dr Khyati \\ *MD Panchakarma \\ **PG Scholar Swasthavritta, UAC, Dehradun \\ DOI: 10.29322/IJSRP.11.01.2021.p10968 \\ http://dx.doi.org/10.29322/IJSRP.11.01.2021.p10968
}

\begin{abstract}
Diabetes Mellitus is a disease which hampers body functions and structure by its complications in long run. Madumehaj Vrana (Diabetic Foot Ulcer) is a major Complication leading to maximum number of Amputations in India and world. A report shows that 30 percent of patients gets healed with the Standard treatment in 20 weeks, which is not an encouraging situation as 70 percent of them will continuously be impacted. So there is a need of accessible affordable and fast technique for management of Madhumehaj Vrana. Raktamokshana through Jalauka is such a powerful Para surgical Procedure which can be the boon to society. It has been clearly mentioned by Acharya Sushruta that Jalaukavcharana can be easily done in any person who is Parama Sukumara, and it removes the deep seated vitiated doshas and improves blood circulation thereby increasing the healing of ulcer fast . In this Case study of Chronic Madhumehaj Vrana Jaluka application was done every 15 days followed by cleaning and washing with yashtimadhu churna and panchavalkala kashaya followd by dressing with Jatyadi tail. Patient was continued the Anti diabetic and Anti Hypertensive medications. After 2 months of treatment Ulcer healed completely.
\end{abstract}

Keywords: Madhumehaj Vrana, Jalaukavcharana, Diabetic Foot Ulcer, Acharya Sushruta

\section{INTRODUCTION}

Diabetic Foot Ulcer is the major complication of Diabetes Mellitus. It is a syndrome involving Neuropathy, Ischemia, infection, poor wound healing due to increased Blood Sugar Level, minor trauma, cutaneous ulceration, gangrene. $85 \%$ of diabetic foot ulcer leads to Amputation, resulting in disability. A study shows that $30 \%$ of Neuropathic Diabetic ulcers heals in 20 weeks with the standard treatment, which is a long duration, so we need an accessible, affordable and fast working treatment. Diabetic foot ulcer mostly occurs on This publication is licensed under Creative Commons Attribution CC BY. planter regions especially at the weight bearing surfaces. According to Ayurveda it can be correlated with Madhumehaj Vrana. Acharya sushruta in Pramehanidana chapter explained that a Pramehi whose body is filled with Vasa and Meda along with other dushyas and vitiated Tridoshas leads to formation of Prameha pidikas and further putrifaction leads to ulcer formation. Acharaya Sushruta also mentioned in Sutrathana Krityakrityavidhi chapter that Madhumehaj Vrana are Kashtasadhya i.e. difficult to treat because of poor wound healing. and in chikitsa sthana it is described that due to weakness of Rasayanis (dhamani that circulates Rasa, Rakta etc) Doshas cannot raise above resulting in Pramehapidikas in lower body only.

\section{IMPORTANCE OF JALAUKAVCHARANA}

Raktamokshana is considered as Ardhachikitsa, as it removes the vitiated doshas from body. Raktamokshana through Jalauka is considered best to be done in Parama Sukukmara as it is an Anushastra and has less threshold to pain. Jalauka lives in water and is Madhura Rasa yukta which is why it is helpful in Pitta vitiated conditions. according to ashtanga hridaya Jalaokavcharana should be done when Doshas are deep seated i.e. Avghada, which means Diabetic foot ulcer can be treated with Jaloukavcharana.as the Doshas are deep seated in Dhatus.

\section{CASE REPORT}

\section{A. AIM AND OBJECTIVES}

To study the effect of Jalokavcharana in Diabetic Foot Ulcer (Madhumehaj Vrana)

\section{B. TYPE OF STUDY}

Observational Single case design without control group. 
C. STUDY CENTRE: AYUSH Dispensary,, Civil Hospital, Sector 4, Rewari, Haryana, India

D. STUDY DETAILS

AGE: 50 yrs

GENDER: Male RELIGION:

Hindu

\section{OCCUPATION: Farmer DIET: Vegetarian}

CHIEF COMPLAINTS: Non Healing Ulcer on Right Foot Planter region since 3 years

Blood discharge along with pus and unpleasant smell and swelling

\section{BRIEF HISTORY}

Patient presented with the complaint of Non healing ulcer on Right Foot Planter aspect accompanied with bloody discharge pus and swelling since 3 years. No History of trauma given by patient. No complaint of any pain. Patient is a case of Diabetes Mellitus and on Medication still Uncontrolled. Patient was a case of uncontrolled Hypertension also and not on any treatment. Patient took allopathic treatment since 3 years but got no relief.

\section{GENERAL EXAMINATION}

Vitals : BP: 200/100 mm Hg Uncontrolled

Haematological investigations: Random Blood Sugar: $417 \mathrm{mg} / \mathrm{dl}$ uncontrolled throughout the course

$\mathrm{X}$ ray AP/Lat/Oblique- No Bony Involvement

\section{LOCAL EXAMINATION AND ASSESSMENT}

\section{a) $\underline{\text { INSPECTION }}$}

SITE: Right Foot Planter Region

SIZE: LENGTH: $3 \mathrm{~cm}$ WIDTH: $3 \mathrm{~cm}$ DEPTH: $0.5 \mathrm{~cm}$

SHAPE: Irregular/oval EDGE: Rough/Irregular FLOOR: Unhealthy with slough and less granulation tissue DISCHARGE: Blood discharge accompanied with pus SMELL: unpleasant

\section{STATE OF VRANA: Dushta Vrana}

\section{b) PALPATION}

EDGE: No Tenderness

Base: No Tenderness

Local Temperature: Raised

\section{PROCEDURE}

This publication is licensed under Creative Commons Attribution CC BY http://dx.doi.org/10.29322/IJSRP.11.01.2021.p10968
After whole assessment wound was washed and cleaned with NS. Afterwards Jalauka was Applied over the wound.

After about 30 minutes jalauka left on their own and wound was cleaned and washed with Yashtimadhu churnalepana and Panchvalkala Kashaya and dressing was done with Jatyadi tail.

Further dressing was done on alternate days and Jalauka was applied once in 15 days for 5 sittings and assessment was done on Day 1, 15, 30, 45, 60. Anti Diabetic drugs( Tab Metformin and Tab Tinagliptin $5 \mathrm{mg}$ ) were advised to continue.

Along with this oral medication of Tab Kaishora Guggulu, Tab Chandraprabhavati 2 BD each and Triphala Churna 5 gm BD and Panchanimba Churna 5 gm BD was given.Also Antihypertensive drugs Tab Amlodipine AT were started.

Observation was done upon the cardinal symptoms for healing of ulcer as follows:

Table 1: Gradation Criteria for Assessment

\begin{tabular}{|c|c|c|c|c|}
\hline $\begin{array}{l}\text { CARDINA } \\
\text { L } \\
\text { SYMPTO } \\
\text { MS }\end{array}$ & GRADE 0 & $\begin{array}{l}\text { GRADE } \\
1\end{array}$ & $\begin{array}{l}\text { GRADE } \\
2\end{array}$ & $\begin{array}{l}\text { GRADE } \\
3\end{array}$ \\
\hline SIZE & $\begin{array}{l}\text { No } \\
\text { discontinui } \\
\text { ty }\end{array}$ & $\begin{array}{l}\text { 3/4th of } \\
\text { previous } \\
\text { area of } \\
\text { ulcer }\end{array}$ & $\begin{array}{l}\text { 1/2th of } \\
\text { previous } \\
\text { area of } \\
\text { ulcer }\end{array}$ & $\begin{array}{l}\text { More } \\
\text { than } \\
1 / 2 \text { th } \\
\text { area of } \\
\text { ulcer }\end{array}$ \\
\hline PAIN & No pain & $\begin{array}{l}\text { Mild } \\
\text { localised } \\
\text { pain on } \\
\text { moveme } \\
\text { nt }\end{array}$ & $\begin{array}{l}\text { Moderate } \\
\text { pain on } \\
\text { rest }\end{array}$ & $\begin{array}{l}\text { Unbearab } \\
\text { le pain } \\
\text { even on } \\
\text { rest }\end{array}$ \\
\hline SMELL & No smell & $\begin{array}{l}\text { Bad } \\
\text { smell }\end{array}$ & $\begin{array}{l}\text { Tolerable } \\
\text { unpleasa } \\
\text { nt }\end{array}$ & $\begin{array}{l}\text { Foul } \\
\text { smell }\end{array}$ \\
\hline $\begin{array}{l}\text { DISCHAR } \\
\text { GE }\end{array}$ & $\begin{array}{l}\text { No } \\
\text { discharge }\end{array}$ & $\begin{array}{l}\text { Mild } \\
\text { occasion } \\
\text { al } \\
\text { discharge }\end{array}$ & $\begin{array}{l}\text { Moderate } \\
\text { discharge } \\
\text { needs } \\
\text { dressing } \\
\text { daily }\end{array}$ & $\begin{array}{l}\text { Profuse } \\
\text { discharge }\end{array}$ \\
\hline EDGE & Intact skin & $\begin{array}{l}\text { Smooth } \\
\text { regular }\end{array}$ & $\begin{array}{l}\text { Rough } \\
\text { and } \\
\text { irregular }\end{array}$ & $\begin{array}{l}\text { Angry } \\
\text { Look }\end{array}$ \\
\hline FLOOR & $\begin{array}{l}\text { Smooth } \\
\text { with } \\
\text { healthy } \\
\text { Granulatio } \\
\mathrm{n} \text { tissue }\end{array}$ & $\begin{array}{l}\text { Rough } \\
\text { regular } \\
\text { less } \\
\text { granulati } \\
\text { on tissue }\end{array}$ & $\begin{array}{l}\text { Unhealth } \\
\text { y , less } \\
\text { granulati } \\
\text { on tissue }\end{array}$ & $\begin{array}{l}\text { Unhealth } \\
\text { y no } \\
\text { granulati } \\
\text { on tissue }\end{array}$ \\
\hline
\end{tabular}

\section{OBSERVATIONS}

Table 2: Observations according to Assessment Criteria

\begin{tabular}{|l|l|l|l|l|l|}
\hline CARDINA & $\begin{array}{l}\text { BEFORE } \\
\text { L }\end{array}$ & & & & A.T \\
\hline
\end{tabular}




\begin{tabular}{|l|l|l|l|l|l|}
\hline $\begin{array}{l}\text { SYMPTO } \\
\text { MS }\end{array}$ & NT & N & \\
\hline SIZE & 3 & $\begin{array}{l}\text { DAY } \\
15\end{array}$ & $\begin{array}{l}\text { DAY } \\
30\end{array}$ & $\begin{array}{l}\text { DAY } \\
45\end{array}$ & $\begin{array}{l}\text { DAY } \\
60\end{array}$ \\
\hline PAIN & 0 & 3 & 2 & 1 & 0 \\
\hline SMELL & 2 & 0 & 0 & 0 & 0 \\
\hline $\begin{array}{l}\text { DISCHAR } \\
\text { GE }\end{array}$ & 2 & 2 & 1 & 0 & 0 \\
\hline EDGE & 3 & 2 & 1 & 0 & 0 \\
\hline FLOOR & 3 & 2 & 2 & 1 & 0 \\
\hline
\end{tabular}

[6] Kaundal Ramesh, Sharma Omprakash, Kumar Gaurav Garg, Hiremath Jyoti, Kumar Ashwani, "Jalaukavcharana (Hirudotherapy): A Unique Parasurgical Measure". Int. J. Ayur. Pharma Research, 2015:3(2): 29-34.

\section{RESULT}

It has been observed that by Jalaukavcharana, Madhumehaj Vrana is healed completely in duration of two months. Jalauka showed its Vrana Shodhana and Ropana effects by removing the vitiated doshas from the affected region and increased healing by improving the blood circulation and decreasing inflammation of the planter region of the foot.

\section{CONCLUSION}

Jalaukavcharana is simple, accessible, affordable and fast technique to cure such Chronic Non healing and Advanced conditions that too in an OPD. As Madhumehaj Vrana shows marked Improvement in 2 months it can be concluded that this bloodletting therapy is truely the Adhachikitsa and boon to the Society. It nearly avoided the chance for Amputation and Disability, which restored the physical level of Health.

\section{REFERENCES}

[1] Kaviraj Ambika Dutt Shastri (Reprint 2016). "Sushruta Samhita Ayurvedatatvasandipika Hindi Commenary "(Vol. Part 1). Varanasi: Chaukhamba Sanskrit Sansthan.

[2] Kaviraj Ambika Dutt Shastri (Reprint 2016). "Sushruta Samhita Ayurvedatatvasandipika Hindi Commenary" (Vol. Part 2). Varanasi: Chaukhamba Sanskrit Sansthan.

[3] Kaviraj Atridev Gupt (Reprint 2013). "Ashtanga Hridyam Vaidyotini Hindi Commentary". Varanasi:

Chaukhamba Prakashan.

[4] Amarprakash P. Dwiwedi , "Case Study of Leech Application in Diabetic Foot Ulcer". Int. J. Res. Ayur Pharm 2012; 3(5):748-751.

[5] Dr Jignesh Chauhan, D. D. (2017)."A Comparative Clinical Study Of Siravedha And Jalaukavcharana In The Management of MadhuMehaj Vrana(Diabetic Foot Ulcer)". World Journal Of Pharmaceutical Research , 6 (7), 1837-1844 This publication is licensed under Creative Commons Attribution CC BY.

\section{FIGURE 3}

DAY 30

\section{0}

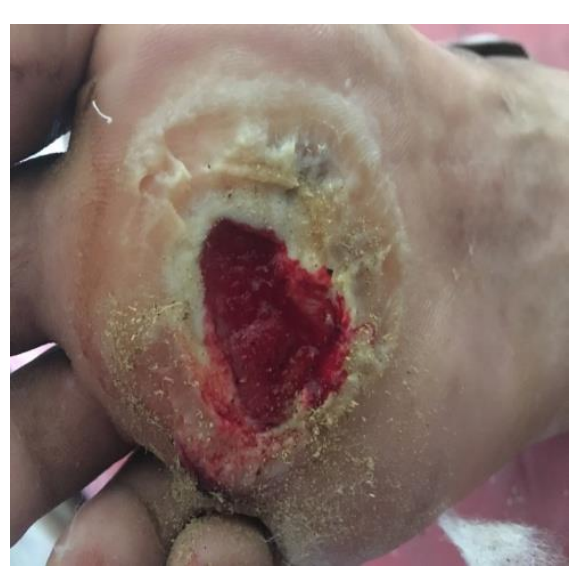

FIGURE 2

\section{DAY 15}

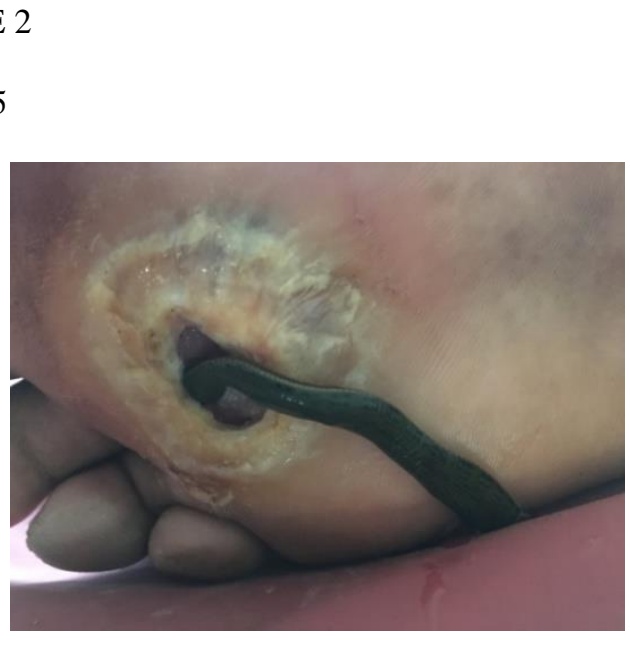

\section{PICTURES}

\section{FIGURE 1}

Clinical Presentation DAY 1 


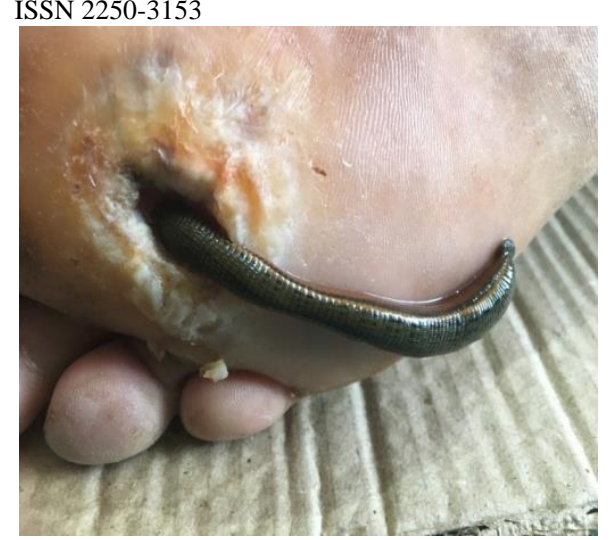

\section{FIGURE 4}

\section{DAY 45}

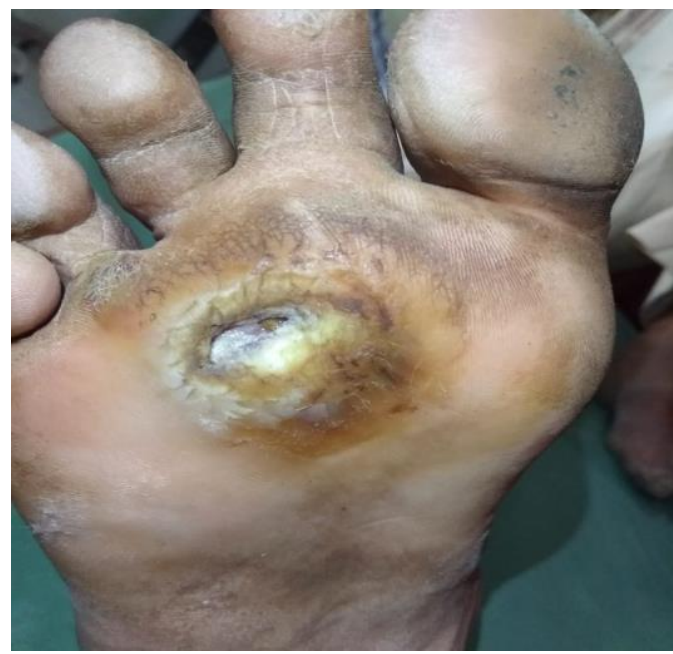

DAY 60

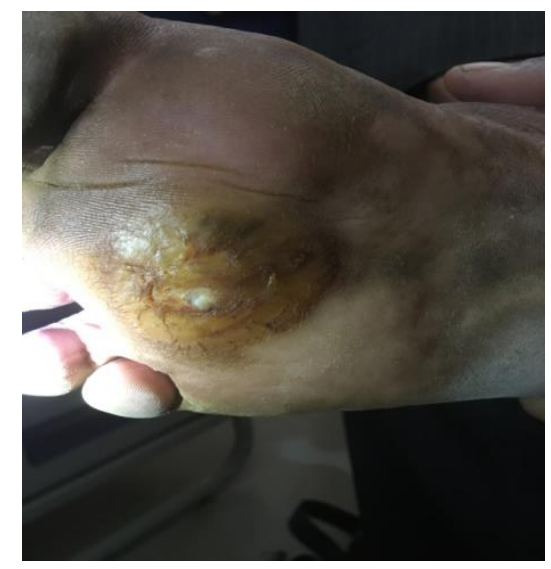

\section{AUTHORS}

Author: Dr Balyogeshwar Sharma, MD Panchakarma.

Email ID: vasisth.yogi3@gmail.com

Contact Number: 7411377820

Correspondence Author: Dr Khyati, PG Scholar Swasthavritta, UAC, Dehradun

Contact Number: 9878021551

Email ID: khyatikaloiya09@gmail.com

\section{FIGURE 5}

